\title{
DATING OF THE REO SITE (ISLAND OF SAAREMAA, ESTONIA) WITH SILICATE AND IRON MICROSPHERULES POINTS TO AN EXACT AGE OF THE FALL OF THE KAALI METEORITE
}

\author{
TANEL MOORA ${ }^{1}$, ANTO RAUKAS ${ }^{2}$ and WOJCIECH T. J. STANKOWSKI ${ }^{3}$ \\ ${ }^{I}$ Institute of History, Tallinn University, Rüütli 6, 10130 Tallinn, Estonia \\ ${ }^{2}$ Institute of Ecology, Tallinn University, Uus-Sadama 5, 10120, Tallinn, Estonia \\ ${ }^{3}$ Institute of Geology, Adam Mickiewicz University, Makow Polnych 16, 61-606 Poznan, Poland
}

Received 19 March 2012

Accepted 25 May 2012

\begin{abstract}
Pollen analyses and radiocarbon dates from the bottom sediments in the Kaali main crater suggested that the crater group is at least 4000-5000 years old. Investigations of silicate impact microspherules in surrounding mires (Raukas et al. 1995) put the age about 7500-7600 yr BP. Recently we found both silicate and iron microspherules from organic sediments below well-dated beach ridge in Reo site what supports the conclusions that the most realistic age of the Kaali craters is $7600 \pm 50{ }^{14} \mathrm{C}$ $\mathrm{BP}(8335-8537 \mathrm{cal} \mathrm{BP})$ and the meteorite fall was from SSE to NNW.
\end{abstract}

Keywords: silicate and iron microspherules, meteorite fall, meteorite craters, radiocarbon and OSL dates.

\section{INTRODUCTION}

Investigation of Kaali impact craters $\left(58^{\circ} 24^{\prime} \mathrm{N}\right.$, $\left.22^{\circ} 40^{\prime} \mathrm{E}\right), 19 \mathrm{~km} \mathrm{NE}$ of the town of Kuressaare on Saaremaa Island, has a long history. During last ten years the authors investigated the Kaali craters through the common project "Extraterrestrial material and impact structures in Poland and Estonia", coordinated by the Estonian Academy of Sciences and the Polish Academy of Sciences. Main attention was paid to find out the suitability of luminescence (TL and OSL) dating techniques for establishing a precise age of the impact craters in Estonia and Poland (Raukas and Stankowski, 2010, 2011; Stankowski et al., 2007). Recently we reinvestigated and dated organic sediments with impact silicate and cosmic iron microspherules below a beach ridge in Reo, $7.5 \mathrm{~km}$

Corresponding author: W. T. J. Stankowski

e-mail: stawgeo@amu.edu.pl

ISSN 1897-1695 (online), 1733-8387 (print)

(C) 2012 Silesian University of Technology, Gliwice, Poland.

All rights reserved. south from the Kaali main crater, pointing to an exact age of meteorite craters and indicating the meteorite fall from southeast to northwest. This direction can be concluded also on the base of dispersal ellipse of craters: small craters behind the main crater (Fig. 1).

\section{BRIEF HISTORY OF FORMER STUDIES}

Already the first investigator of craters Ivan Reinwald $^{1}$ (Reinvaldt, 1933) maintained that the Kaali craters were formed some 4000-5000 BP. The same opinion had in his first papers also Ago Aaloe (1958). The craters were formed after the retreat of the Baltic Sea from this part of Saaremaa because marine sediments in craters are absent. This implies that they must be younger than 9000 ${ }^{14} \mathrm{C}$ years (All ${ }^{14} \mathrm{C}$ dates we used, in lab. ages and relevant calibrated intervals - see Table 1).

\footnotetext{
${ }^{1}$ In the scientific literature the name Reinwald is written in different ways: Reinwald, Reinwaldt, Reinvalt. In this paper the first variant is used.
} 


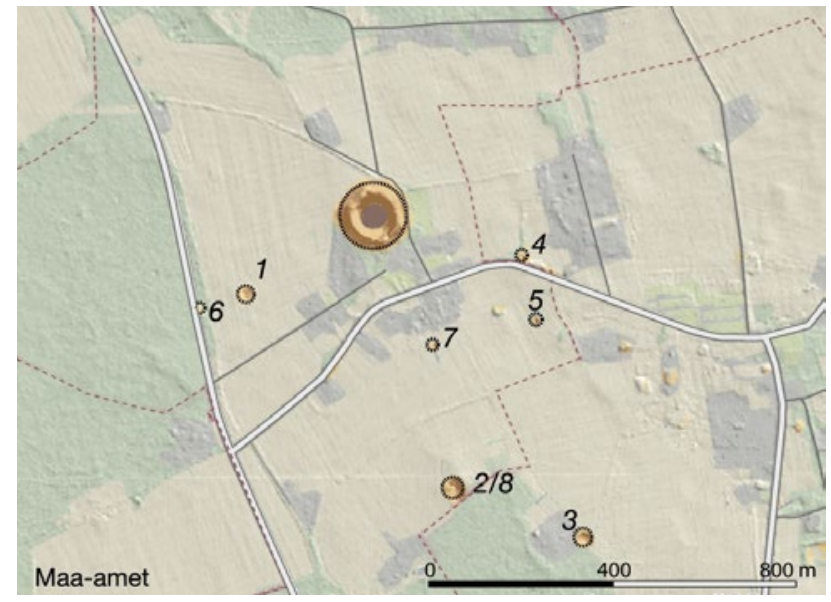

Fig. 1. Location of the Kaali impact craters. Numbers indicate the location of small craters. Lidar projection of the Estonian Land Board.

Based on an iridium content in peat Rasmussen et al. (2000) and Veski et al. $(2001,2002,2004)$ concluded that the Kaali impact took place much later, about 800-400 BC (2800-2400 BP). This conclusion is clearly wrong. The pollen spectrum from the bottom deposits of Lake Kaali has been dated as approx. 3700 years old (Kessel, 1981) and the radiocarbon dating has yielded an age of about $4000{ }^{14} \mathrm{C}$ BP (Saarse et al., 1991), but undoubtedly it is only the minimum age, because the accumulation of organic sediments in Lake Kaali started a rather long time after the impact. Already peat from a depth of 1.18-1.25 $\mathrm{m}$ gave the age of $2958 \pm 51{ }^{14} \mathrm{C}$ BP $(\mathrm{T} \ln -2576)$, which after calibration is some $3220-3000$ cal BP. Pollution is excluded, because a tree trunk from a nearby excavation yielded an age of $2673 \pm 47{ }^{14} \mathrm{C} \mathrm{BP}(\mathrm{T} \ln -2573)$.

Investigation of silicate impact spherules in surrounding peat bogs (Raukas et al. 1995, Raukas 2000) put the age about $7500-7600{ }^{14} \mathrm{C}$ BP and it was supported by luminescent dating. Stankowski concluded (Raukas and Stankowski, 2010; 2011) that the luminescent dates about 7000 years BP indicate the moment of sedimentary infilling which must have started almost immediately after the creation of craters (data from no. 7 crater infilling material - two indicators for semi-bottom and middle section part, about $7 \mathrm{ka}$ ).

Until a few years ago we have found in the surroundings of Kaali only buried silicate microspherules. But recently a long search of iron spherules has been richly rewarded in Reo site, where the first author found both silicate and iron microspherules from the peaty histosol below a well-dated beach ridge.

\section{INVESTIGATION OF SILICATE AND IRON FINES IN KAALI AREA}

The Kaali iron meteorite belongs to the IA group of coarse octahedrites and its fragments in the Kaali crater field are rich in forms, colours and composition (Raukas,
Table 1. Results of radiocarbon dating. Dates were calibrated with using OxCal programme (Bronk Ramsey, 2009) and InCal09 calibration curve (Reimer et al., 2009).

\begin{tabular}{|c|c|c|c|}
\hline No. & Lab. code & $\begin{array}{l}{ }^{14} \mathrm{C} \text { age } \\
(\mathrm{BP} \pm 1 \sigma)\end{array}$ & $\begin{array}{l}\text { Calibrated age } \\
68.2 \% \text { conf. intervals } \\
\text { (cal BP) }\end{array}$ \\
\hline 1 & TIn-2576 & $2958 \pm 51$ & $3220-3000$ \\
\hline 2 & Tln-2573 & $2673 \pm 47$ & $\begin{array}{l}2850-2820(15.3 \%) \\
2800-2740(52.9 \%)\end{array}$ \\
\hline 3 & Tln-1972 & $7586 \pm 67$ & $8450-8330$ \\
\hline 4 & TIn-1973 & $7669 \pm 46$ & $8520-8410$ \\
\hline 5 & TIn-2278 & $7558 \pm 65$ & $8430-8310$ \\
\hline 6 & TIn-254 & $7350 \pm 70$ & $\begin{array}{c}8290-8260(8.0 \%) \\
8210-8040(60.2 \%)\end{array}$ \\
\hline 7 & TIn-253 & $7165 \pm 70$ & $\begin{array}{c}8050-7930(63.4 \%) \\
7900-7870(4.8 \%)\end{array}$ \\
\hline 8 & TIn-3246 & $9498 \pm 70$ & $\begin{array}{c}11070-10950(25.9 \%) \\
10870-10840(3.3 \%) \\
10810-10650(37.9 \%) \\
10620-10600(1.1 \%)\end{array}$ \\
\hline 9 & Tln-2558 & $7368 \pm 68$ & $\begin{array}{l}8320-8150(54,2 \%) \\
8120-8050(13.9 \%) \\
\end{array}$ \\
\hline 10 & Tln-2554 & $7730 \pm 120$ & $8640-8390$ \\
\hline
\end{tabular}

2004, Marini et al., 2004). According to Aaloe and Tiirmaa (1981), with some later modifications (Shymanovich et al., 1993), the following main types of extraterrestrial matter occur in the Kaali crater field and surroundings:

1) Meteoritic iron formed as a result of the break-up of the meteorite in the atmosphere and its disintegration at the moment of impact. It occurs in the form of irregular tiny meteorite fragments and fine (mainly less than $1 \mathrm{~mm}$ ) pulverized particles with a variety of shapes.

2) Meteoritic dust formed as a result of melting and evaporation of the rapidly upheated meteoroid during its entering of the Earth's atmosphere. The products of evaporation are represented by magnetite globules and platelets, varying in shape, internal structure and microsculpture. Globules may be spherical, rounded elliptic, ovatetubercular or drop-like.

3) Microimpactites formed on the melting and vaporization of meteoritic matter and target rocks during the impact. Both magnetite-silicate and silicate formations have been discovered.

In the second half of the 1970-s, to elaborate the direction of the meteorite fall, a systematic study of the fragments of meteors and diffuse material from satellite craters and surface sediments was carried out in the crater field (Aaloe and Tiirmaa, 1981). The work was extended on Muhu Island and also on the mainland (Tiirmaa, 1988). The first results showed that the meteorite fall was from east or northeast. The study of spherules from surface sediments met critical opponents who did not consider it possible to tell the difference between the ancient meteorite material and the pollution coming from con- 
temporary smithery, welding and from the chimneys of factories, located in eastern direction. Thanks to justified critics the second author got the idea of looking for meteorite diffuse material in the vicinity of Kaali in the mire deposits not having industrial influence (Fig. 2).

Glassy silicate microspherules (microimpactites) were found in the Lower Atlantic peat of Piila mire about 10 $\mathrm{km}$ northwest of the Kaali craters in the layer at a depth of 300-310 cm dated at $7586 \pm 67(\mathrm{~T} \ln -1972), 7669 \pm 46$ (Tln-1973) and $7558 \pm 65(\mathrm{~T} \ln -2278){ }^{14} \mathrm{C}$ BP (Raukas et al., 1995, 1999). Microspherules of the same age were discovered also in the Peli mire, ca. $18 \mathrm{~km}$ northwest of the Kaali craters, in the Pitkasoo mire in the western part of Saaremaa, about $27 \mathrm{~km}$ southwest of Kaali and in the Kõivasoo mire on the Hiiumaa Island ca. $65 \mathrm{~km}$ from the craters (Fig. 2, Raukas, 1997). The chemical composition of glassy microimpactites is diverse, being controlled by the character of the target rocks (Raukas, 2004). Some spherules consist mainly of silica and calcium, others from calcium and iron, and a third set of silica with a small quantity of calcium. They contain an admixture of iron and nickel, sometimes also cobalt, specific for iron meteorites. In all the above-mentioned mires, silicate microspherules were detected only in one layer showing

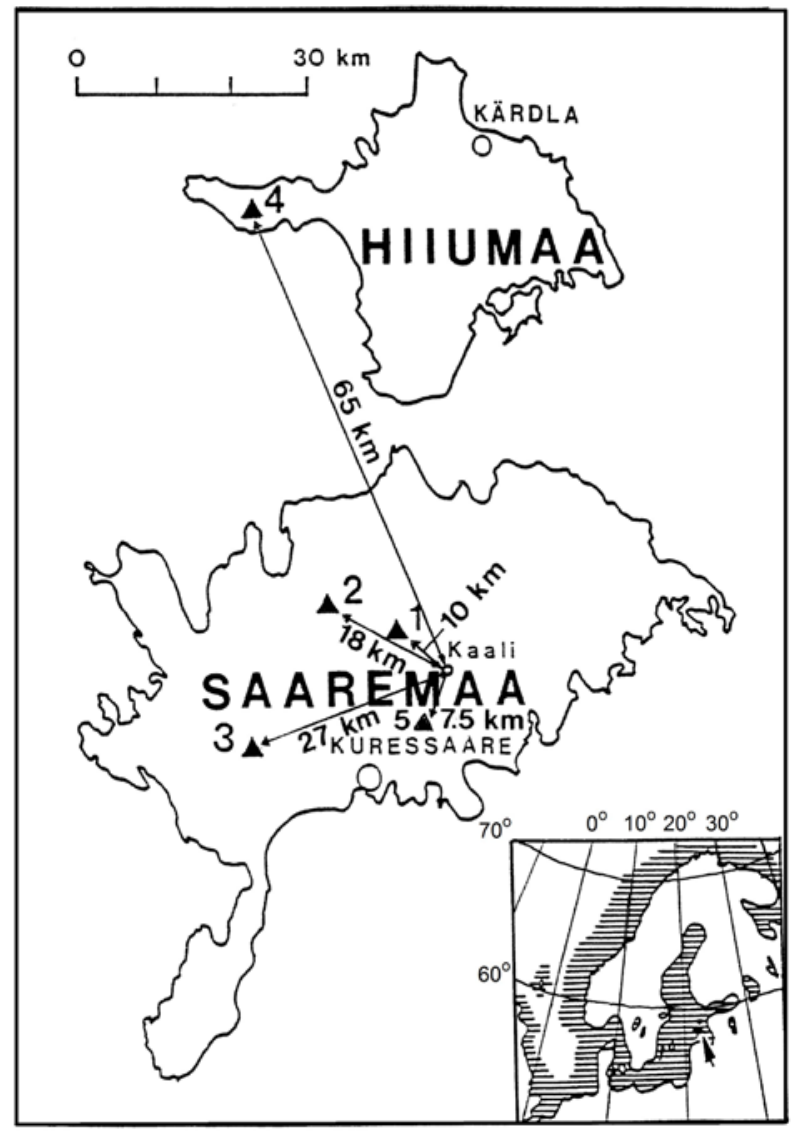

Fig. 2. Location of investigated sites: 1 - Piila; 2 - Pelisoo; 3 - Pitkasoo; 4 - Kõivasoo; 5 - Reo. the exact age of the meteorite impact. As a result of the Kaali impact, the heated gas stream reached a height of 6.8-7.9 km (Raukas and Laigna, 2005) and the distribution of small glassy silicate microimpactites over a vast area was a normal process. In 2000 the age of Ilumetsa meteorite fall in South-East Estonia was established (Raukas et al., 2001) using the same method. No iron spherules were found in mire deposits to the $\mathrm{W}$ and $\mathrm{NW}$ from Kaali.

Magnetic fines from the Kaali impact site (Marini et al., 2004) and Reo section were carefully investigated by Dr. Francois Marini. He performed SEM examinations on carbon-coated, 3D particles, coupling classical SE and BSE imaging, and systematic EDS qualitative analysis. Several grains were checked for quantitative study, using standardless XPP quantitation. He found, that Kaali fines record a wide range of air-flight-, impact-, and postimpact processes. All grains contained nickel, the highest $\mathrm{Ni}$ contents appear to have been directly inherited from oxidation of preexisted taenite and schreibersite. In mineral composition kamacite, taenite, schreibersite, hematite, magnetite, goethite, maghemite and wüstite were found, in coated fragments also quartz, feldspars, micas, dolomite, clay minerals and wads; organic coatings always contain $\mathrm{Si}, \mathrm{Ca}, \mathrm{Mg}, \mathrm{C}, \mathrm{Cl}, \mathrm{K}, \mathrm{Na}, \mathrm{P}$ and $\mathrm{S}$. Organic matter most probably originates from organic compounds in the surrounding sediments and from recent soils.

\section{REO - A KEY SECTION FOR THE ESTABLISH- ING OF THE PRECISE AGE OF KAALI CRATERS}

For the establishing of additional proof for the age of the Kaali impact we reinvestigated Reo-Ilpla outcrop (old gravel pit which was exhausted in 1976) between the villages of Ilpla and Reo $\left(58^{\circ} 19^{\prime} \mathrm{N}, 22^{\circ} 40^{\prime} \mathrm{E}\right) 7.5 \mathrm{~km}$ south from the Kaali main crater (Fig. 2). The section is described in detail in Reintam et al. (2008). This paper contains also chemical, agrochemical and grain-size analyses of all layers.

In 1976, Helgi Kessel took several samples from the Kilbumäe gravel pit, which were analysed by her palynologically and dated by J.- M. Punning who received an age of $7350 \pm 70{ }^{14} \mathrm{C}$ BP (Tln-254) for the lower part and $7165 \pm 70{ }^{14} \mathrm{C}$ BP (Tln-253) for the upper part of the organic-rich layer. On the $14 \mathrm{~m}$ contour line marked in Fig. $\mathbf{5}$, in the gravel pit near the Reo graveyard there is a layer rich in birch and pine trunks. The oldest of these were recently dated to $9498 \pm 70 \mathrm{BP}{ }^{14} \mathrm{C} \mathrm{BP}(\mathrm{T} \ln -3246)$.

Between 1999 and 2008, the section was thoroughly investigated by the first author who tried to find impact spherules. First iron spherule was picked up by R. Tiirmaa in 2003. In 2008 at the Reo site both silica and iron microspherules were found. Buried under coastal ridge organic material (Fig. 3) was dated in the radiocarbon laboratory of the Institute of Geology at Tallinn University of Technology by E. Kaup. The upper part of the layer gave an age of $7368 \pm 68 \mathrm{BP}{ }^{14} \mathrm{C} \mathrm{BP}(\mathrm{Tln}-2558)$ and lower $10 \mathrm{~cm}$ an age of 
$7730 \pm 120{ }^{14} \mathrm{C}$ BP (Tln-2554), well coinciding with the age of spherules from the mire sections. Silica microimpactites and cosmic iron microspherules (Fig. 4) were mineralogically and chemically investigated by $\mathrm{F}$. Marini from National Research Center in Vandoeuvre-les-Nancy Cedex, France. Pedogenetic analysis of the layer was done by $\mathrm{L}$. Reintam (Reintam et al., 2008).

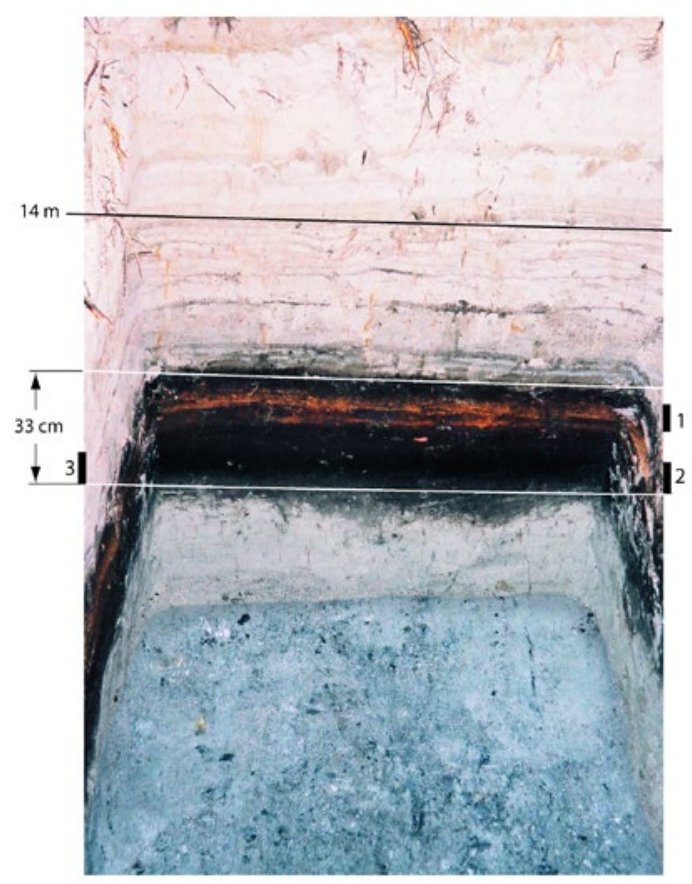

Fig. 3. Buried organic layer with iron and silicate spherules between marine sands. Black piles from the right hand of the layer show the sampling points for the ${ }^{14} \mathrm{C}$ dating. The age of the lower part of the layer yielded $7350 \pm 70$ (TIn-254) and that of the upper part $7165 \pm 70$ (TIn-253) ${ }^{14} \mathrm{C}$ BP. Photo by T. Moora.

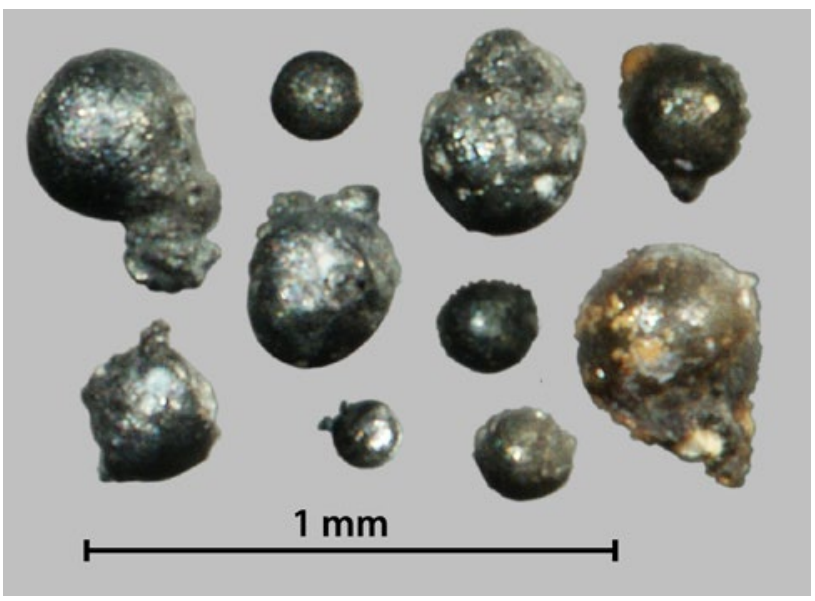

Fig. 4. Iron spherules from the Reo Kilbumägi section. Photo by G. Baranov.
The Holocene history of Reo-Ilpla area (Fig. 5) is typical for the Island of Saaremaa (Raukas, 1997; Raukas et al., 1995). During the regressions of the Baltic Ice Lake and the Yoldia Sea the study area was dry land in the situation of islands or islets. In Pre-Boreal about $9300{ }^{14} \mathrm{C}$ BP thin silty-sandy sediments of the Ancylus Lake transgression covered the limestone surface here. If it is assumed that shallow water of the Ancylus Lake rapidly retreated from islet-like bedrock and tilly hillocks, the duration of hydromorphic pedogenesis must have been at least 2000 years until Litorina transgression once again buried the formed soil profiles under the sandy carpet. The Late Ancylus pedogenesis in Boreal Chronozone resulted in the formation of Eutric Histosol during about two millennia or even for some hundred years less.

Up to now, opinions differ as to the direction from south to northeast and angle of incidence of the Kaali meteorite. On the basis of the size and location of the craters, Reinwald (1937) and Krinov (1961) came to the conclusion that the direction of movement was from the SSE to NNW and according to Kovalevski (1954) from south to north. The morphology of the wall of the main crater, sparse geophysical data available in the destruction zones of the main and secondary craters 1 and 6 (Aaloe et al., 1982) and the distribution of dispersed

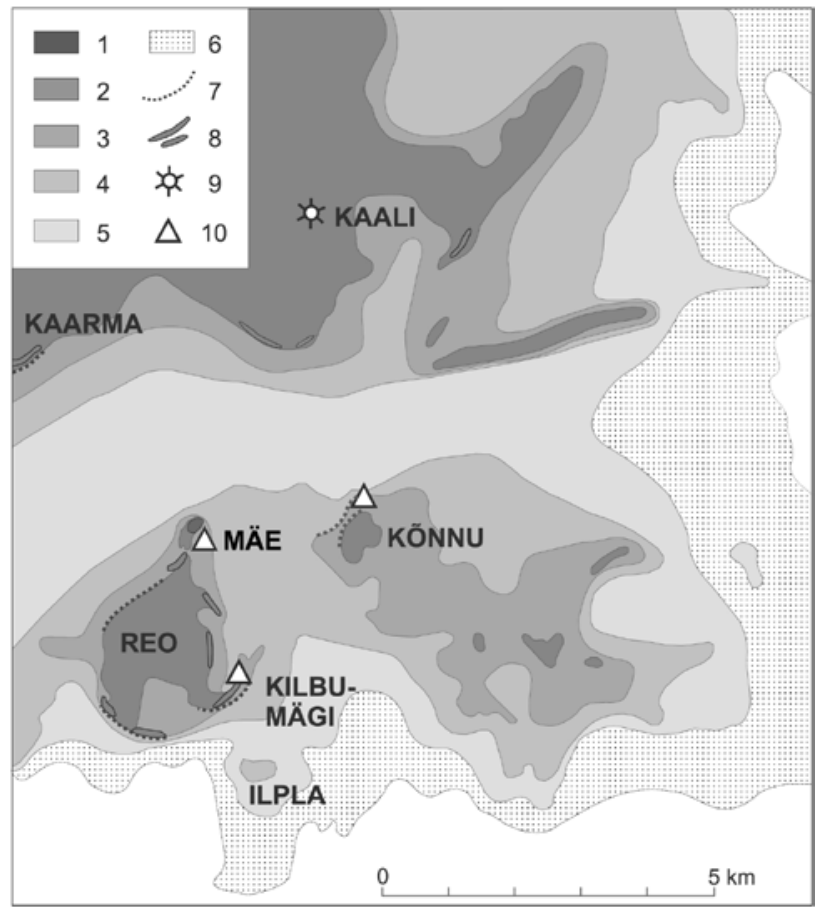

Fig. 5. Palaeogeographical map of the Reo-llpla area: 1 and 2 - phases of the retreat of the Ancylus Lake; 3 - area of the maximum transgression of the Litorina Sea; 4, 5 and 6-most important shorelines of the retreating Litorina Sea and the shoreline of the Limnea Sea; 7 - coastal scarps of the Litorina Sea maximum; 8 - beach barriers of the Litorina Sea maximum transgression; 9 - Kaali craters; 10 - early Neolithic Kõnnu settlement. Buried organic layers were found at Kilbumägi and Mäe. 
material in the craters and outside of the crater field (Aaloe and Tiirmaa, 1981, 1982, Tiirmaa, 1988) suggested that the meteorite probably fell from the east-northeast over the Pandivere elevation. This idea was strongly supported by archaeologists (Lõugas, 1996) and the former president of Estonia Lennart Meri (Meri, 1976). As we already mentioned, the magnetic spherules in surficial layers of the Estonian mainland, which according to Aaloe and Tiirmaa (1982) show the fall trajectory, are mostly industrial in origin and were probably transported to Saaremaa and western Estonia by winds from the industrial region of northeastern Estonia and Tallinn. Therefore, the explanation by Reinwald (1937), Krinov (1961) and Kovalevski (1954) is much more reasonable and now supported also by factual data from Reo.

\section{CONCLUSIONS}

In the Reo section we found cosmic iron globules for the first time. It allows to draw two important conclusions: 1) the most realistic age of the Kaali craters is $7600 \pm 50 \mathrm{yr}$ BP (8335-8537 calibrated years in OxCal) and 2) the metorite fall was probably from SSE to NNW, because meteorite with a greater mass maintains its initial cosmic velocity for a longer time than smaller ones (Fig. 1). Therefore, the larger one should be in front of the dispersal ellipse, and the smaller ones behind it in decreasing order (Krinov, 1961). It explains the content of pulverised and melted iron meteoritic particles (mainly less than $1 \mathrm{~mm}$ in diameter) in the organic matter to the south of craters. During the impact, much silicate matter from the Earth was thrown into the air as well and glassy silicate spherules mixed with the iron particles. Other our investigated sites were to the west or north-west from the craters (Fig. 2) and therefore they contained only silicate spherules. The performed interdisciplinary studies assert, that Kaali craters are most probably $7600 \pm 50$ radiocarbon years old (Raukas and Stankowski, 2011). In this paper we used conventional radiocarbon dates. In calibrated radiocarbon years the impact took place some 8440 years ago.

\section{ACKNOWLEDGEMENTS}

The authors thank Mrs Reet Tiirmaa for separating impact spherules, Dr. Francois Marini for complex studies of different types of spherules in the Kaali crater field and surroundings and Prof. Loit Reintam for common field studies in Reo section. Our sincere thanks belong to reviewers of the manuscript. We are much obliged to the editor of the manuscript Dr Danuta Michczyńska for the improving our text and adding the Table 1, which helps the using of ${ }^{14} \mathrm{C}$ dates.

\section{REFERENCES}

Aaloe A, 1958. Kaalijärve meteoriidikraatri Nr. 5 uurimisest 1955. aastal (Investigation of meteorite crater No.5 of the Kaalijärv group in 1955). Eesti NSV Teaduste Akadeemia Geoloogia Instituudi Uurimused II. Eesti Riiklik Kirjastus, Tallinn: 105-117.

Aaloe A, Andra Valve and Andra H, 1982. Napravlenie padenia meteoritnogo doždya Kaali po geofizitšeskim dannym (Determination, by geophysical methods, of the direction of the meteoritic rain at Kaali). Eesti NSV Teaduste Akadeemia Toimetised, Geoloogia 31(2): 56-61 (in Russian, with English and Estonian summaries).

Aaloe A and Tiirmaa R, 1981. Raspõlyonnoe meteoritnoe i impaktnoe vestsestvo na kraternom pole Kaali [Pulverized and impactite meteoritic matter in the Kaali crater field\}. Eesti NSV Teaduste Akadeemia Toimetised. Geoloogia 30(1): 20-27 (in Russian with Estonian and Russian summaries).

Aaloe AO and Tiirmaa RT, 1982. Meteoritnoe vestsestvo v melkih kraterah Kaali i ego okrestnosti [Meteoritic matter in small craters of Kaali and neighbourhood]. Meteoritika 41: 120-125 (in Russian).

Bronk Ramsey C, 2009. Bayesian analysis of radiocarbon dates. Radiocarbon 51(1): 337-360.

Kessel H, 1981. Kui vanad on Kaali järviku põhjasetted? (How old are the bottom deposits of Lake Kaali?). Eesti Loodus 4: 150-155 (in Estonian, with English and Russian summaries).

Kovalevski SA, 1954. Meteorit Faeton. [Meteorit Phaeton]. Priroda 2: 90-92 (in Russian).

Krinov EL, 1961. The Kaalijärv meteorite craters on Saaremaa Island, Estonian SSR. American Journal of Science 259(6): 430-440, DOI 10.2475/ajs.259.6.430.

Lõugas V, 1996. Kaali kraatriväljal Phaetonit otsimas (Investigating of the Phaeton in the Kaali crater field). Tallinn, Eesti Entsüklopeediakirjastus: $175 \mathrm{pp}$.

Marini F, Raukas A and Tiirmaa R, 2004. Magnetic fines from the Kaali impact-site (Holocene, Estonia): Preliminary SEM investigation. Geochemical Journal 38: 211-219.

Meri L, 1976. Hõbevalge (Silber white). Tallinn, Eesti Raamat: 488 pp.

Rasmussen LK, Aaby B and Gwozdz R, 2000. The age of the Kaalijärv meteorite craters. Meteoritics \& Planetary Science 35(5): 10671071, DOI 10.1111/j.1945-5100.2000.tb01493.x.

Raukas A, 1997. Evolution of the Baltic Sea. In: Raukas A and Teedumäe A, eds., Geology and Mineral Resources of Estonia. Estonian Academy Publishers, Tallinn: 268-274.

Raukas A, 2000. Investigation of impact spherules - a new promising method for the correlation of Quaternary deposits. Quaternary International 68-71: 241-252, DOI 10.1016/S1040-6182(00)000471.

Raukas A, 2004. Distribution and composition of impact and extraterrestrial spherules in the Kaali area (Island of Saaremaa, Estonia). Geochemical Journal 38: 101-106.

Raukas A and Laigna K-O, 2005. Height of the turbulent gas flow and transport distance of glassy spherules on the example of the Kaali impact, Estonia. Proceedings of the Estonian Academy of Sciences, Geology 54(3): 145-152.

Raukas A, Pirrus R, Rajamäe R and Tiirmaa R, 1995. On the age of meteorite craters at Kaali (Saaremaa Island, Estonia). Proceedings of the Estonian Academy of Sciences, Geology 44(3): 177-183.

Raukas A, Pirrus R, Rajamäe R and Tiirmaa R, 1999. Tracing the age of the catastrophic impact event in sedimentary sequences around the Kaali meteorite craters on the Island of Saaremaa, Estonia. Journal of the European Network of Scientific and Technical Cooperation for the Cultural Heritage (PACT) 57: 435-453.

Raukas A and Stankowski W, 2010. The Kaali crater field and other geosites of Saaremaa Island (Estonia): the perspectives for a geopark. Geologos 16(1): 59-68, DOI 10.2478/v10118-010-0004-z.

Raukas A and Stankowski W, 2011. On the age of the Kaali craters, Island of Saaremaa, Estonia. Baltica 24(1): 37-44.

Raukas A, Tiirmaa R, Kaup E and Kimmel K, 2001. The age of the Ilumetsa meteorite craters in southeast Estonia. Meteoritics \& Planetary Science 36(11): 1507-1514, DOI 10.1111/j.19455100.2001.tb01842.x.

Reimer PJ, Baillie MGL, Bard E, Bayliss A, Beck JW, Blackwell PG, Bronk Ramsey C, Buck CE, Burr GS, Edwards RL, Friedrich M, Grootes PM, Guilderson TP, Hajdas I, Heaton TJ, Hogg AG, Hughen KA, Kaiser KF, Kromer B, McCormac FG, Manning SW, 
Reimer RW, Richards DA, Southon JR, Talamo S, Turney CSM, van der Plicht J, 2009. IntCal09 and Marine09 Radiocarbon Age Calibration Curves, 0-50,000 Years cal BP. Radiocarbon 51(4): 1111-1150.

Reintam L, Moora T and Raukas A, 2008. Gleysols on sandy deposits of the Litorina Sea underlain by Histosol formations of Ancylus Lake age in western Estonia. Estonian Journal of Earth Sciences 57(4): 231-240, DOI 10.3176/earth.2008.4.03.

Reinvaldt I, 1933. Kaali järv - the Meteorite Craters on the Island of Ösel (Estonia). Loodusuurijate Seltsi Aruanded 39: 183-202.

Reinwald I, 1937. Kaali järve meteoorkraatrite väli [The Kaalijärv field of meteorite craters]. Loodusvaatleja 4: 97-102 (in Estonian).

Saarse L, Rajamäe R, Heinsalu A and Vassiljev J, 1991. The biostratigraphy of sediments deposited in the Lake Kaali meteorite impact structure, Saaremaa Island, Estonia. Bulletin of the Geological Society of Finland 63: 129-139.

Shymanovich S, Kolosova T, Raukas A and Tiirmaa R, 1993. Extraterrestrial spherules in the surroundings of Kaali meteorite craters (Saaremaa Island, Estonia). Proceedings of the Estonian Academy of Sciences, Geology 42(3): 127-133.

Stankowski WTJ, Raukas A Bluszcz A and Fedorowicz S, 2007. Luminescence dating of the Morasko (Poland), Kaali, Ilumetsa and Tsõõrikmäe (Estonia) meteorite craters. Geochronometria 28: 2529, DOI 10.2478/v10003-007-0031-0.

Tiirmaa R, 1988. Rasprostranenie raspõlyonnogo meteoritnogo vestset va na kraternom pole Kaali [Distribution of pulverized meteoritic matter in the Kaali crater field]. Proceedings of the Estonian Academy of Sciences, Geology 37(1): 43-46 [in Russian with Estonian and Russian summaries].Veski S, Heinsalu A, Kirsimäe K, Poska A and Saarse L, 2001. Kaali meteorite impact induced ecological catastrophe $800-400 \mathrm{BC}$, as revealed by pollen, XRD, LOI and ${ }^{14} \mathrm{C}$ analyses of peat containing impact ejecta. In: $6^{\text {th }} E S F-$ IMPACT Workshop Impact Markers in the Stratigraphic Record. Abstract Book. Granada (Spain) May 19-25, 200: 132-135.

Veski S, Heinsalu A, Kirsimäe K, Poska A and Saarse L, 2001. Ecological catastrophe in connection with the impact of the Kaali meteorite about 800-400 B.C. on the island of Saaremaa, Estonia. Meteoritics \& Planetary Science 36(10): 1367-1375, DOI 10.1111/j.1945-5100.2001.tb01830.x.

Veski S, Heinsalu A and Kirsimäe K, 2002. Kaali meteoriidi vanus ja mõju looduskeskkonnale Saaremaa Piila raba turbaläbilõike uuringu põhjal (The age of the Kaali meteorite and the effect of the impact on the environment: evidence from Piila bog. Island of Saaremaa, Estonia). Eesti Arheoloogia Ajakiri 6(2): 3-20 (in Estonian with English summary).

Veski S, Heinsalu A, Lang V, Kestlane Ü and Possnert G, 2004. The age of the Kaali meteorite craters and the effect of the impact on the environment and man: evidence from inside the Kaali craters, island of Saaremaa, Estonia. Vegetation History and Archaeobotany 13(3): 197-206, DOI 10.1007/s00334-004-0043-x. 